\title{
Response of rosemary plant to the effect of Nano-NPK fertilizer and biological factors and their effect on the active substances
}

\author{
${ }^{1}$ Hamid H. Mahewish, ${ }^{2}$ Falah H. Radi, ${ }^{3}$ Mohammed N . Radhi \\ ${ }^{1,2,3}$ University of Thi- Qar, College of Agriculture and Marshlands, Department of Horticulture and Garden Engineering \\ 1Email: hamidh199154@gmail.com
}

\begin{abstract}
:
The study was carried out in the canopy-covered by Alsaran of the Faculty of Agriculture and marshes University of ThiQar on 01.11.2020. The experiment was terminated on 15.06.2021 On the rosemary plant that old of age was one year at three seedlings per unit experimental, thus became the number of seedlings 81 Seedlings in plastic anvils, container on sandy loam soil and peat moss with a percentage $3: 1$ The experiment included the treatment of the balanced compound Nano-NPK fertilizer by spray on leaves of the plant at concentrations $(0,25,75) \mathrm{mg} . \mathrm{l}^{-1}$ by three times for a period 15 th day between one adding and another, and the biological factor was added at concentrations $(0,10,20) \mathrm{ml}$ by one adding. And carried out an experiment factorial according to Randomized Complete Block Design RCBD With three replications for each treatment, the results were compared according to the least significant difference test at the probability level of $5 \%$. The statistical analysis results showed superiority in the compound Nano-fertilizer by height and number of branches, amount of oil and its density, and some of the active substances Cymen And the Camphene And Rose Mari

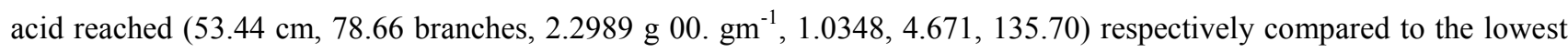
value for the comparison treatment. The biological factor was superior in the following characteristics (height, branches number, oil quantity, oil density, and active compounds). Cymen and the Camphene and Rose Mari acid reached (49.77 $\mathrm{cm}, 67.44$ ) and $2.3277 \mathrm{~g} .100 . \mathrm{g}^{-1}$ ), respectively, compared with the lowest value for comparative treatment. As for the interaction, the treatment outperformed N2B2 In the adjective of the number of branches insignificant, and the treatment of N2B1 In the amount of oil, oil density and some active compounds, Rose Mari acid. It had a significant effect on the treatment N0B1 Significant effect on the active compound Camphene.
\end{abstract}

\section{INTRODUCTION}

The importance of medicinal plants and herbs has multiplied, and their use is frequent in many fields, including nutrition, treatment, medicine, and some flavors added to foods and many drinks. They are considered among the primary sources of medicinal drugs and a source of active substances used in the pharmaceutical industry (Evans et al., 2003). Many plants contain Chemical compounds that are considered of great importance in the treatment of many diseases and were used in different forms. One of the important plants widely used in food, medicine and perfumes is the rosemary plant (Rosmarinus officinalis L.), which belongs to the family Labiatae (Lamiaceae). It is called the mint family; it is one of the large families, as it contains 180 genus and 3500 species. The importance of the rosemary plant came as it is one of the plants that contain volatile oils that contain more than 25 oily compounds (Roa et al., 1998). The plant has medicinal 


\section{University of Thi-Qar Journal of agricultural research}

\section{ISSN Onlin:2708-9347, ISSN Print: 2708-9339 Volume 10, Issue 1 (2021) PP 39 - 48}

\section{https://jam.utq.edu.iq/index.php/main $\quad$ https://10.54174/UTJagr.Vo10.N1/04}

and non-medical uses as an additive for taste and flavor and as a spice. It is also used in the manufacture of aromatherapy, aromatic soaps, and cosmetics. The oil is used medicinally as an aromatic, stimulant, anti-inflammation, and a carminative, and as a diaphoretic in fever cases (Diaphoretic) (Heikal and Omar, 1993). The Rosemary plant is used to treat many diseases, including analgesics for convulsions, nerve stimulants, memory boosters, relieving headache, tension and nervous stress, sedative for pain, and anti-cancer (Ruwaiha, 1984). Rosemary is a good gas repellent because it contains flavonoids and anti-depressants and anti-convulsive because it contains volatile oils. It is also used in massage ointments. It contains phenolics and anti-microbial diseases because it contains diterpenes. It works to increase menstruation because it contains oleanolic acid by taking the extract. The aqueous extract of the plant and anti-inflammatory because it contains carnosol, and it is considered as an anti-carcinogen and anti-cirrhosis of the liver when using the alcoholic extract of the whole plant, especially carnosol, as well as other substances, the most important of which are carnosic acid, ursolic acid, betulin acid, rosmaridiphenol, rosmanol and cymene. Researches indicated that chemical fertilization affected plant growth and the amountof extracted volatile oil. Nitrogen fertilization led to increased plant growth and anincrease in oil yield (Bell and Coorts, 1979 and Westervelt, 2003). Biofertilizers areused to reduce the addition of chemical fertilizers by no less than (25\%), in addition to their role in reducing environmental pollution problems (Singh et al., 2002). Due to the importance of the oil and its multiple uses, interest in aromatic plants in general, including rosemary plants, has increased. A wide range of cultivation has taken place. Farmers have provided an ideal environment with the best conditions that suit the plant to successfully cultivate it in new areas that differ environmentally from the areas of its natural presence. This study aimed to: firstly was knowing the effect of treating the rosemary plant with different concentrations of the compound Nano-fertilizer and the possibility of some changes that can give better characteristics for vegetative growth and increase the active substances of the plant. Secondly was detecting changes that occur when adding the biological factor of characteristics of the plant's vegetative growth and active substances.

\section{MATERIALS AND METHODS}

The experiment was conducted in the canopy of the Department of Horticulture and Garden Engineering of the College of Agriculture and Marshes - University of Thi-Qar. The study was conducted in 2020-2021. The rosemary seedlings were selected after obtaining the Al-Ahlia plant nursery in Dhi Qar Governorate on October 1, 2020. The selection of homogeneous seedlings was taken into account in its size and growth as much as possible. The seedlings were transferred to large-sized anvils with a diameter of $24 \mathrm{~cm}$ and a height of $26 \mathrm{~cm}$ (10 kg capacity) filled with soil and peat moss $1: 3$ to provide the natural conditions suitable for the plant as much as possible. Samples were taken from the medium before starting the experiment to conduct laboratory tests on them, as shown in table 1 . 
University of Thi-Qar Journal of agricultural research

ISSN Onlin:2708-9347, ISSN Print: 2708-9339 Volume 10, Issue 1 (2021) PP 39 - 48

https://jam.utq.edu.iq/index.php/main $\quad$ https://10.54174/UTJagr.Vo10.N1/04

Table (1) Chemical and physical characteristics of the soil properties used in the experiment

\begin{tabular}{|l|l|l|}
\hline Properties & Measuring unit & Value \\
\hline PH & - & 7.3 \\
\hline EC & $\mathrm{ml} . \mathrm{cm}$ & 2.49 \\
\hline Tissue & sandy loam & \\
\hline Sand & $\mathrm{g} . \mathrm{kg}^{-1}$ & 70 \\
\hline Loam & $\mathrm{g} . \mathrm{kg}^{-1}$ & $15^{\text {th }}$ \\
\hline Clay & $\mathrm{g} . \mathrm{kg}^{-1}$ & $15^{\text {th }}$ \\
\hline $\mathrm{N}$ & $\mathrm{ml.1^{-1 }}$ & 25.88 \\
\hline P & $\mathrm{ml.1}$ & 7.11 \\
\hline $\mathrm{K}$ & $\mathrm{ml.1}$ & 118.96 \\
\hline
\end{tabular}

$A$.

\section{B. Study factors}

The experiment involved two factors:

The first factor: The compound Nano-NPK fertilizer by three concentrations $(0,25,75) \mathrm{mg}$, it contains NPK elements 20:20:20: it is a product manufactured by Al-Khadra for the production of chelated Nano-fertilizers in Iran which was added as a spray In the early morning until complete wetness at a rate of three additions on $20.11,05.12,20 / 12$. The second factor: the biological factor, Pseudomonas fluorescens bacteria, with three concentrations $(0,10,20) \mathrm{ml}$ at a rate of one addition at 25.11 .

Table (2) the components of King B medium for bacterial development

\begin{tabular}{|l|l|}
\hline Peptone & $20 \mathrm{gm}$ \\
\hline K2HPO4 & $5 \mathrm{gm} .1$ \\
\hline MgSO4 & $5 \mathrm{gm} .1$ \\
\hline Glycerin & $10 \mathrm{gm}$ \\
\hline Distilled Water & $1 \mathrm{~L}$ \\
\hline
\end{tabular}




\section{Development and multiplication of the bacteria Pseudomonas fluorescens}

KB liquid King medium broth (King et al., 1954) was prepared (Table 2); the source of the bacterial inoculum was obtained from the plant protection department, College of Agriculture, Basra University. Where 1 liter was prepared and distributed into $100 \mathrm{ml}$ beakers and kept in the refrigerator until use. The bacterial vaccine was added by $1 \mathrm{ml}$ to each beaker when needed and incubated at a temperature of $30 \mathrm{C}$ for a period of time 48 hours. To determine the number of colony-producing cells, the suspension was diluted and grown on KBA (King broth Agar) medium by taking $1 \mathrm{ml}$ of the diluted bacterial suspension, spreading it on the solid medium and keeping it at a temperature of $\mathrm{C}$ for 24 hours.

\section{Experimental design}

The results were statistically analyzed using the Genstat program. The differences were compared arithmetic averages of the Least Significant Differences Test (LSD) results at a 5\% probability level (Al-Rawi and Khalaf Allah, 2000).

\section{E. $\quad$ Studied traits}

1- Number of leaves (1-leaf)

The total number of leaves of plants was calculated at the end of the experiment by calculating the number of leaves for a branch one and multiply it by the number of branches (number of leaves in one branch * number of branches)

\section{2- Total chlorophyll content of leaves}

The total chlorophyll dye in the leaves was estimated according to the method of Zaehringer et al. (1974). $0.5 \mathrm{gm}$ of fresh leaves was taken and the dye was extracted using $80 \%$ acetone and it was measured with a Spectrophotometer at two wavelengths 645 and $663 \mathrm{~nm}$, according to the amount of dye by applying the following equation:

Total Chlorophyll(mg.L-1) $=20.2 \mathrm{D}(654)+8.02 \mathrm{D}(663) * \mathrm{v} / 1000 * \mathrm{w}$

$=\mathrm{D}$ stands for wavelength reading

$\mathrm{V}=$ final volume $(\mathrm{ml})$

$\mathrm{W}=$ sample weight $(\mathrm{g})$

\section{3- Determination of Total Carbohydrate:}

The total carbohydrate content was estimated by the (Hedge and Hofreiter) method. (0.2 gm) of the sample to be measured is added to it $(25 \mathrm{ml})$ of perchloric acid $(1 \mathrm{~N})$ and placed in a test tube, then the tubes are placed in a water bath at a temperature of (60) for (30 minutes) after which the sample is filtered using filter papers. (( $1 \mathrm{ml}$ of the filtrate and add to it $(9 \mathrm{ml})$ of distilled water to complete the volume to $(10 \mathrm{ml})$ in a volumetric bottle. $1 \mathrm{ml})$ is taken from the last and a concentration of phenol $(5 \%+5 \mathrm{ml}))$, concentrated sulfuric acid, is added to it and left until it cools. It is measured at a wavelength $(490 \mathrm{~nm})$ with a spectrophotometer that prepares several concentrations of glucose $(10,20,30,40,50$, $60,70)$ and the absorbance of the above readings is recorded (to make a calibration curve). 
4- Determination of phosphorous concentration (P\%)

The phosphorous content of leaves was calculated according to the method of Chapman and Pratt (1961), by weighing $0.5 \mathrm{gm}$ of the crushed and dried sample and dissolved in $5 \mathrm{ml}$ of sulfuric acid and $2 \mathrm{ml}$ of prochloric acid. Ammonium molybdate and ascorbic acid were used (the colorimetric method), then they were measured using a spectro photometer (type UK - 22 Libra - Bichrom 2005) at a wavelength of $700 \mathrm{~nm}$.

5- Determination of potassium concentration (\% K)

The model was analyzed in the laboratories of the Department of Environment and Water / Ministry of Science and Technology to estimate the total potassium concentrations according to the method mentioned by (Wodaje Addis2017.) and a (Photoelectric Flame Photometer) model (BWB) was used to measure potassium K) in the model.

\section{RESULTS}

A- The effect of Nano-NPK fertilizer and the biological factor and their interaction on the vegetative growth characteristics of rosemary plants:

\section{1- Number of leaves (1-leaf)}

The results of Table (3) showed that the effect of nano-fertilizer on the rate of increased plant leaves was significant; the factor $N 2$ with a concentration of $75 \mathrm{mg} . \mathrm{l}-1$ recorded a higher average of 1660.33 leaf plant ${ }^{1-}$ relative to $N 1$ with a concentration of 25 mg.l-1 which gave 1288.66, respectively, which outperformed all of them. On the comparison treatment that gave the lowest mean value of 824 . The biological factor had a significant effect on plant leaves; the treatment $B 2$ at a concentration of $20 \mathrm{ml}$ gave 1422.66 that outperformed treatment B1, which gave 1243. The comparison treatment gave 1107.33. The results of this table showed that the interaction had a non-significant effect. This is attributed to the fact that leaves levels of added nitrogen may lead to stimulating auxins and their transfer in plant tissues at leaves rates, which helps to elongate cells of the vegetative system, as the leaves concentrations are found in the growing top of a plant, this means that the leaves concentrations are found in buds and growing tops of stems, as the auxins work on cell elongation. The results of this study agree with what was reached by Westervelt (2003) that the leaves of the rosemary plant increases with increasing nitrogen fertilization to a certain extent. This result was identical to what Ihsan (1999) found when fertilizing Mint (Mentha spicata) and Longifolia (Mentha longifolia) when noticed that nitrogen fertilization led to an increase in plant leaves compared to unfertilized plants. The increase in plant leaves by increasing the levels of added phosphorous is due to the prominent role of the biological factor that increases the readiness of this element in plant growth. 
University of Thi-Qar Journal of agricultural research

ISSN Onlin:2708-9347, ISSN Print: 2708-9339 Volume 10, Issue 1 (2021) PP 39 - 48

https://jam.utq.edu.iq/index.php/main $\quad$ https://10.54174/UTJagr.Vo10.N1/04

Table (3) effect of compound Nano-fertilization and biological factors and their interactions on Number of leaves (1-leaf)

\begin{tabular}{|c|c|c|c|c|}
\hline \multirow{2}{*}{ Nano fertilizer } & \multicolumn{3}{|c|}{ Biological factor } & \multirow[t]{2}{*}{ Fertilization Mean } \\
\hline & B0 & $\bar{B} 1$ & B2 & \\
\hline N0 & 681 & 819 & 972 & 824 \\
\hline N1 & 1208 & 1289 & 1369 & 1288.66 \\
\hline $\mathrm{N} 2$ & 1433 & 1621 & 1927 & 1660.33 \\
\hline Biological factor Mean & 1107.33 & 1243 & 1422.66 & \\
\hline 05 & \multicolumn{2}{|c|}{$.0 \mathrm{LSD}$} & & \\
\hline $\mathrm{N}=159.8$ & \multicolumn{2}{|l|}{$\mathrm{B}=159.8$} & \multicolumn{2}{|c|}{$\mathrm{N} * \mathrm{~B}=\mathrm{NS}$} \\
\hline
\end{tabular}

\section{2- Total chlorophyll content of leaves}

The results in Table (4) showed that the effect of the compound nano-fertilizer increase the Total chlorophyll content of leaves was significant, the factor $\mathrm{N} 2$ at a concentration of $75 \mathrm{mg} . \mathrm{l}^{-1}$, recorded the highest average of 7.155 relative to N1 with a concentration of $25 \mathrm{mg}$. $\mathrm{l}^{-1}$, which gave 5.292, respectively, all of that outperformed than comparison treatment that gave the lowest mean of 4.051. Also, the biological factor had a significant effect on Total chlorophyll content of leaves; the treatment $\mathrm{B} 2$ at a concentration of $20 \mathrm{ml}$ gave 6.007 , which outperformed treatment $\mathrm{B} 1$, which gave 5.55 , as well as outperformed the comparison treatment that gave 4.941. The results included in that table showed that the interaction had a significant effect; the treatment N2B2 was superior, which amounted to 8.167on the control treatment that gave the lowest value for this trait, 3.713.

Table (4) effect of compound Nano-fertilization and biological factors and their interactions on Total chlorophyll content of leaves

\begin{tabular}{|c|c|c|c|c|c|}
\hline \multirow{2}{*}{ Nano fertilizer } & \multicolumn{4}{|c|}{ Biological factor } & \multirow{2}{*}{$\begin{array}{l}\text { Fertilization } \\
\text { Mean }\end{array}$} \\
\hline & B0 & B1 & B2 & & \\
\hline No & 3.713 & 4.217 & 4.223 & & 4.051 \\
\hline N1 & 4.950 & 5.293 & 5.633 & & 5.292 \\
\hline N2 & 6.160 & 7.140 & 8.167 & & 7.155 \\
\hline Biological factor Mean & 4.941 & 5.55 & 6.007 & & \\
\hline \multicolumn{6}{|c|}{.0 LSD } \\
\hline $\mathrm{N}=\mathbf{0 . 2 4}$ & \multicolumn{3}{|l|}{$B=0.24$} & \multicolumn{2}{|l|}{$\mathrm{N} * \mathrm{~B}=0.42$} \\
\hline
\end{tabular}




\section{University of Thi-Qar Journal of agricultural research}

ISSN Onlin:2708-9347, ISSN Print: 2708-9339 Volume 10, Issue 1 (2021) PP 39 - 48

\section{https://jam.utq.edu.iq/index.php/main $\quad$ https://10.54174/UTJagr.Vo10.N1/04}

\section{3-Determination of Total Carbohydrate:}

Table (5) showed that the effect of compound Nano-fertilizer on the rate of increase in Carbohydrate was significant. N2 with a concentration of $75 \mathrm{mg}$. I-1 recorded the highest average of 21.882 . Treatment N1 with a concentration of $25 \mathrm{mg}$. ${ }^{1} 1$, which gave 21.518 in a row, all of which outperformed the control treatment, which gave the lowest mean value of 20.738. Also, the biological factor had a significant effect on the amount of oil; treatment B2 with a concentration of $20 \mathrm{ml}$ gave 21.848outperformed treatment B1, which gave 21.618also outperformed than control treatment which gave 20.671. The results listed in this table showed that the interaction had a significant effect; the treatment N2B1 was superior, which Carbohydrate to 22.380 on the control treatment, which gave the lowest value for this trait 20.166. This is attributed to the fact that nanofertilizers increase the availability of ready-made nutrients to the plant in a longer period and with a release that matches the growth of the plant, which increases the formation of chlorophyll and the rate of photosynthesis, and as a result, the overall growth increases, and this in turn leads to an increase in the concentration of total carbohydrates. The significant increase of carbohydrates can be attributed to the role of the elements The major ones, especially nitrogen, which acts as a regulator for the action of growth hormones, cytokines and auxins, These results are in agreement with the results of (Al-Taie, 2017) when using nano-NPK on the anise plant.

Table (5) effect of compound Nano-fertilization and biological factors and their interactions Carbohydrate in rosemary leaves

\begin{tabular}{|c|c|c|c|c|}
\hline \multirow{2}{*}{ Nano fertilizer } & \multicolumn{3}{|c|}{ Biological factor } & \multirow[t]{2}{*}{ Fertilization Mean } \\
\hline & B0 & B1 & B2 & \\
\hline N0 & 20.166 & 20.693 & 21.356 & 20.738 \\
\hline N1 & 20.816 & 21.783 & 21.956 & 21.518 \\
\hline $\mathrm{N} 2$ & 21.033 & 22.380 & 22.233 & 21.882 \\
\hline Biological factor Mean & 20.671 & 21.618 & 21.848 & \\
\hline \multicolumn{5}{|c|}{$.0 \mathrm{LSD}$} \\
\hline $\mathrm{N}=0.025$ & \multicolumn{3}{|l|}{$\mathrm{B}=0.025$} & $\mathrm{~N} * \mathrm{~B}=0.044$ \\
\hline
\end{tabular}

\section{4- Determination of phosphorous concentration (P\%)}

The results of Table (6) showed that the effect of the compound Nano-fertilizer on the phosphorous concentration was significant; the factor $\mathrm{N} 2$ with a concentration of $75 \mathrm{mg}$. I-1, recorded the highest average of $0.565 \%$ compared to the research treatment $\mathrm{N} 1$ with a concentration of $25 \mathrm{mg}$. I-1, which gave $0.510 \%$ in a row, all of which outperformed the comparison treatment which gave the lowest mean value of $0.411 \%$. Also, the biological factor had a significant effect on the phosphorous concentration; treatment B2 at a concentration of $20 \mathrm{ml}$ gave $0.559 \%$, which was superior to treatment B1, which gave $0.515 \%$ and the control 


\section{University of Thi-Qar Journal of agricultural research}

ISSN Onlin:2708-9347, ISSN Print: 2708-9339 Volume 10, Issue 1 (2021) PP 39 - 48

\section{https://jam.utq.edu.iq/index.php/main $\quad$ https://10.54174/UTJagr.Vo10.N1/04}

treatment, which gave 0.413 . The results in the table showed that the interaction had a significant effect, and the treatment N2B1, which amounted to 0.626 , outperformed the comparison treatment, which gave the lowest value for this trait0.343.

Table (6) effect of compound Nano-fertilization and biological factors and their interactions on the phosphorous concentration \%of rosemary leaves

\begin{tabular}{|c|c|c|c|c|c|}
\hline \multirow{2}{*}{ Nano fertilizer } & \multicolumn{4}{|c|}{ Biological factor } & \multirow{2}{*}{$\begin{array}{l}\text { Fertilization } \\
\text { Mean }\end{array}$} \\
\hline & B0 & B1 & B2 & & \\
\hline No & 0.343 & 0.386 & 0.506 & & 0.411 \\
\hline N1 & 0.423 & 0.533 & 0.576 & & 0.510 \\
\hline N2 & 0.473 & 0.626 & 0.596 & & 0.565 \\
\hline Biological factor Mean & 0.413 & 0.515 & 0.559 & & \\
\hline \multicolumn{6}{|c|}{.0 LSD } \\
\hline $\mathrm{N} * \mathrm{~B}=\mathbf{0 . 0 1 0}$ & \multicolumn{3}{|l|}{$B=0.006$} & \multicolumn{2}{|l|}{$\mathrm{N}=0.006$} \\
\hline
\end{tabular}

\section{5- Determination of potassium concentration (\% K)}

The results of Table (7) showed that the effect of the compound Nano-fertilizer on the potassium concentration $(\% \mathrm{~K})$ rate was significant; the $\mathrm{N} 2$ plant at a concentration of $75 \mathrm{mg} . \mathrm{I}^{-1}$, recorded the highest average of $6.238 \%$ in relation to treatment $\mathrm{N} 1$ with a concentration of $.25 \mathrm{mg}^{\mathrm{I}^{-1}}$ which gave $6.121 \%$ in a row, all of that outperformed than control treatment that gave the lowest mean value $5.960 \%$. Also, the biological factor had a significant effect on the phosphorous concentration; treatment B2 at a concentration of $20 \mathrm{ml}$ gave $6.208 \%$, which was superior to treatment B1, which gave $6.148 \%$ and the control treatment, which gave 5.964. The results in the table showed that the interaction had a significant effect, and the treatment N2B1, which amounted to $6.346 \%$, outperformed the comparison treatment, which gave the lowest value for this trait5.843\%. As for the significant increase that occurred in the percentage of nitrogen, phosphorous and potassium in the tables (9-10-11), which gave the concentration of $75 \mathrm{mg} \mathrm{L}-1$ the highest values for the averages $(0.689 \%, 0.565 \%, 6.238 \%)$ compared to the comparison treatment $(0.537 \%, 0.411 \%, 5.960 \%)$ (Respectively, the reason for the increase in the aforementioned characteristics is due to the fact that nanofertilizers have a large surface area and particle size less than the pores in plant leaves, which can cause an increase in their penetration into plant tissues, and thus the absorption of nutrients and elements is more efficient and streamlined, and this is that direct absorption from Before the leaves, these elements contributed a lot to increasing the content of the leaves from them, in addition to the fact that the excellent potassium element from the leaves acts as a carrier of nitrate ions, as it transfers them in the form of KNO3 and this agrees with Shahian et al. (2019). Draksaly, (2005) also found that fertilization with nitrogen and phosphorous led to an increase in the percentage of nitrogen and phosphorous in the leaves of rosemary plant. 
Table (7) effect of compound Nano-fertilization and biological factors and their interactions on the content of leaves of a substance $(\% \mathrm{~K})$

\begin{tabular}{|c|c|c|c|c|}
\hline \multirow{2}{*}{ Nano fertilizer } & \multicolumn{3}{|c|}{ Biological factor } & $\begin{array}{c}\text { Fertilization } \\
\text { Mean }\end{array}$ \\
\cline { 2 - 5 } & B0 & B1 & B2 & 5.960 \\
\hline N0 & 5.843 & 5.916 & 6.123 & 6.121 \\
\hline N1 & 5.966 & 6.183 & 6.286 & 6.238 \\
\hline N2 & 6.083 & 6.346 & 6.208 & \\
\hline Biological factor Mean & 5.964 & 6.148 & & \\
\hline \multicolumn{5}{|c|}{ LSD 0.05 } \\
\hline
\end{tabular}

\section{References}

1-Al-Rawi, h, M, and Khalaf, A, A, M. 2000. Design and Analysis of Agricultural Experiments. Ministry of Higher Education and Scientific Research. Iraq.

2-Al-Samarrai, M, H. 2001. Effect of nitrogen and phosphate fertilization and planting date on growth and amount of oil in Dill (Anethum graveolens L.). Master Thesis. Faculty of Agriculture. Baghdad University.

3-Al-Tai, Arkan Ali Shanawa. (2017). Master's Thesis (Comparison of the effect of different levels of ordinary and nanocomposite nano-fertilizer on the growth and chemical content of three types of plants of the tent family) Al-Qadisiyah University.

4-Al-Darkazli, Iraq, Alaa Abdel-Moneim Abbas (2005). Master Thesis (The effect of nitrogen and phosphate fertilization on the vegetative growth of rosemary). College of Agriculture, University of Baghdad

5-Bell, S.M. and G.D. Coorts. 1979. The effects of growth medium of three selected herb sp. Florists Rev., 163: $48-49$

6-Chang, K.H.; J.H. Hwan K.B. Park; D.J. Kang and Y.S. Lee. 1987. Effect of application levels of nitrogen fertilizer on the growth and chemical composition of mint. Research reports of the rural development administration crops (Korea R.). 29 (1): 289-293.

7-Ehsan, S, A. 1999. Study of some factors affecting the quantitative and qualitative characteristics of the essential oils of peppermint and thyme. PhD thesis. Faculty of Agriculture. University of Baghdad - Iraq.

8-Evans, S .B, and .H .T. Maria. 2003. Antioxidant effect of various rosemary (Rosmarinus officinalis L.) clones, Volume 47(1-4): pp 111-113 
9-Heikal, M, S, and Omar, A, R. 1988. Natural and chemically aromatic plants, their productivity, benefits, English Knowledge Foundation, Egypt.

10-Keverson, Z.S; C. Natasa; H. Harabovsk and B. SaKac. 2009.Essential Oil Composition of fresh and dried Pepper fruit Capsicum annum L. for ground paprica product processing .quality and safety. 1, pp.229233.

11-King, E.O., Ward, M.K. and Rangey, D.E.1954. Two simple media for the demonstration of pyocyanin and fluorescein .J. Lab. Clin. Medicine, 44: 301-307.

12-Peter, K. V. 2004. Hand Book of Herbs and Spices. CPC press LIC, North and South America. Pp 215224

13-Roa, L.J.; M. Singh; B. Ragharan and K.O. Abraham 1998. Rosemary (Rosmarinus officinalis L.): Impact of drying on the flavor quality. J. Food Quality, USA. 21 (2): P. 2: P. 107-115.

14-Shahein,M.M., and M.S. Mahmoud .(2019).Effect of Nano-Fertilizers on Cucumber plant groth,19(2):165-172.

15-Ruwaiha, A. 1983 Herbal medicine, seventh edition, Dar Al-Qimm, Beirut, Lebanon.

16-Westervelt, P.M. 2003. Greenhouse production of Rosmarinus officinalis L. Master of Science in Horticultural Science. Blacksburg Virginia. 